\title{
Seroprevalence of SARS-CoV-2 antibodies in broadcast media workers
}

\author{
Paulo Ricardo Martins-Filho, PhD ${ }^{1}$ 2; Danilo Nobre da Silva, B BiomedSc ${ }^{3}$; Danillo Menezes \\ dos Santos, $\mathrm{PhD}^{2}$; Márcia Santos Rezende ${ }^{4}$; Jessica Paloma Rosa Silva, BSPT ${ }^{5}$; Josafá \\ Bonifácio da Silva Neto, B Journ ${ }^{6}$; Dulce Marta Schimieguel, PhD ${ }^{3,4}$; Lucindo José Quintans- \\ Júnior, $\mathrm{PhD}^{2,3,4}$; Jullyana de Souza Siqueira Quintans, $\mathrm{PhD}^{2}$; Paula Santos Nunes, $\mathrm{PhD}^{2}$; \\ Adriano Antunes de Sousa Araújo, $\mathrm{PhD}^{2,3,4}$
}

1 Investigative Pathology Laboratory, Federal University of Sergipe, Aracaju, Sergipe, Brazil.

2 Health Sciences Graduate Program, Federal University of Sergipe, Aracaju, Sergipe, Brazil.

3 Graduate Program in Pharmaceutical Sciences, Federal University of Sergipe, São Cristóvão, Sergipe, Brazil.

4 Department of Pharmacy, Federal University of Sergipe, São Cristóvão, Sergipe, Brazil.

5 Graduate Program in Applied Health Sciences, Federal University of Sergipe, Lagarto, Sergipe, Brazil.

6 Journalism Sector, Radio UFS, Federal University of Sergipe, Aracaju, Sergipe, Brazil.

Address for correspondence: Prof. Paulo Ricardo Martins-Filho. Universidade Federal de Sergipe, Hospital Universitário, Laboratório de Patologia Investigativa. Rua Cláudio Batista, s/n. Sanatório. Aracaju, Sergipe, Brasil. CEP: 49060-100. Email: prmartinsfh@gmail.com

Abstract

In this cross-sectional study, we investigated the seroprevalence of SARS-CoV-2 antibodies in workers of radio and television (TV) in Sergipe state, Northeast Brazil. The study was conducted from December 1 to December 20, 2020, considered the beginning of the second wave of COVID19 in the state. Our findings showed a high seroprevalence of SARS-CoV-2 antibodies in radio and TV workers, especially among those in the production and operation teams. Prevention and control protocols against COVID-19 should be revised and implemented by media companies. Broadcast media workers should be prioritized in COVID-19 vaccine strategies.

Key-words: COVID-19; SARS-CoV-2; Communications Media. 
medRxiv preprint doi: https://doi.org/10.1101/2021.04.29.21256360; this version posted May 2, 2021. The copyright holder for this preprint (which was not certified by peer review) is the author/funder, who has granted medRxiv a license to display the preprint in perpetuity.

All rights reserved. No reuse allowed without permission.

The COVID-19 pandemic has emerged as an unprecedented challenge for journalism activity. ${ }^{1}$ Apart from the uncertainty about job security, broadcast media workers are at increased risk of SARS-CoV-2 infection due to the daily routine of reporting in the field. Recently, the Press Emblem Campaign (PEC) - an international independent nonprofit and non-governmental organization reported that more than 700 journalists died from COVID-19 in 72 countries since March 2020. Peru ranks first in the number of deaths (135), followed by Brazil (129) and Mexico (90) (https://www.pressemblem.ch/pec-news.shtml).

To the best of our knowledge, no seroepidemiological studies were conducted analyzing the presence of SARS-CoV-2 antibodies in broadcast media including workers of radio and television (TV). Surveillance of antibody seropositivity can allow to quantify the extent of infection in a population and proportion of people that remains susceptible to the virus. In this cross-sectional study, we investigated the seroprevalence of SARS-CoV-2 antibodies in radio and TV workers in Sergipe state, Northeast Brazil. The study was conducted from December 1 to December 20, 2020, considered the beginning of the second wave of COVID-19 in the state.

After obtaining written informed consent to participate, individuals were interviewed using a structured questionnaire that included demographic and clinical features. Then, venous blood was collected aseptically using venipuncture and a fluorescence immunoassay (FIA) (iChroma II, BioSys + Kovalent) for qualitative detection and differentiation of $\lg M$ and $\lg G$ antibodies against SARSCoV-2 was performed. A result was considered negative if the automated reader obtained a readout $<0.8$, indeterminate if $\geq 0.8$ and $<1.1$, and positive if $\geq 1.1$. The sensitivity and specificity of the FIA are $95.8 \%$ and $97.0 \%$, respectively, according to the manufacturer when assessed on 46 SARSCoV-2 positive patients and 131 negative controls (http://www.biosys.com.br/wpcontent/themes/transport/covid-19-images/SOLUCAOPOCT-COMPLETA-COVID-19.pdf).

The main outcome in the present study was seroprevalence expressed as the proportion of individuals who had a positive result in the FIA. Broadcast media workers were grouped according to the occupation activity as following: (1) production team (PT); (2) reporting team (RT); and operation team (OT). Pearson's chi-square test was performed to examine differences in seroprevalence by type of media work. Significance level was set at 5\%. Analysis was performed by using R software (version 3.5.3; R Foundation for Statistical Computing, Vienna, Austria). This study was approved by the Ethics Committee of the Federal University of Sergipe (protocol number 33095120.4.0000.5546).

The study included a convenience sample of 113 broadcast media workers (62 PT, 22 RT, and 29 OT). The median age (interquartile range [IQR]) was 39 years (IQR, $30.0-48.0$ ) and most of them were male $(n=79,70.0 \%$ ). The presence of comorbidities (diabetes, hypertension, cardiac disease, or other chronic condition) was reported by 29 (25.7\%) individuals. Forty-two (37.2\%) workers 
medRxiv preprint doi: https://doi.org/10.1101/2021.04.29.21256360; this version posted May 2, 2021. The copyright holder for this preprint

(which was not certified by peer review) is the author/funder, who has granted medRxiv a license to display the preprint in perpetuity.

All rights reserved. No reuse allowed without permission.

described close contact with people presenting SARS-CoV-2 infection in the last two weeks of the serological assay and the use of facial mask during work activities was reported in most cases $(\mathrm{n}=$ $110,97.3 \%)$.

Twenty-eight broadcast media workers had detectable levels of SARS-CoV-2 antibodies (11 IgM+, $6 \mathrm{lgM}+/ \mathrm{lgG}+$, and $11 \mathrm{lgG}+$ ) and the estimated seroprevalence was $24.7 \%(95 \% \mathrm{Cl} 17.7-33.5)$. There was no statistical difference in the seroprevalence between occupational activities $(\mathrm{p}=$ $0.715)$, but OT $(27.6 \%, 95 \% \mathrm{Cl} 14.7-45.7)$ and PT $(25.8 \%, 95 \% \mathrm{Cl} 16.6$ - 37.9) presented higher estimates than RT $(18.2 \%, 95 \%$ Cl $7.3-38.5)$ (Table 1).

Despite the massive interest in social networking services for information sharing and Internet use, traditional media remains the most important channel through which COVID-19 information is communicated. $^{2}$ Faced with the need for real-time coverage of COVID-19 information in several settings, broadcast media workers are at increased risk of SARS-CoV-2 infection. Ensuring that a media worker has the personal protective equipment (PPE) and support they need to work safely has become critical during this unprecedented global sanitary crisis.

In this study, we found a high seroprevalence estimate in radio and TV workers and a large proportion of individuals with serological results suggestive of active phase or recent SARS-CoV-2 infection. These findings indicate a high exposure of broadcast media workers to the SARS-CoV-2 and the circulation of these individuals in the work environment unaware that they are infected with the virus. It has been shown that SARS-CoV-2 may spread asymptomatically in a population even under social distancing restrictions. ${ }^{3}$

Interesting, our results showed a lower seroprevalence for SARS-CoV-2 antibodies among journalists, reporters, and videographers of broadcast media. It is possible that RT, considered the high-risk group for SARS-CoV-2 infection, is more careful regarding COVID-19 protective measures due to the need for contact with the external public during work activities. In contrast, PT and OT usually work inside TV newsrooms which may increase the risk of infection in an indoor environment. There is evidence that closed indoor spaces with minimal ventilation rate provide an ideal environmental for SARS-CoV-2 transmission. ${ }^{4,5}$

This study showed a high seroprevalence of SARS-CoV-2 antibodies in radio and TV workers, especially among those in the production and operation teams. Prevention and control protocols against COVID-19 should be revised and implemented by media companies. Broadcast media workers should be prioritized in COVID-19 vaccine strategies. Further seroepidemiological studies should evaluate the exposure of freelancers and print and digital media professionals to SARSCoV-2 infection. 
medRxiv preprint doi: https://doi.org/10.1101/2021.04.29.21256360; this version posted May 2, 2021. The copyright holder for this preprint (which was not certified by peer review) is the author/funder, who has granted medRxiv a license to display the preprint in perpetuity.

\section{References}

1. Ferreira GB, Borges S. Media and Misinformation in Times of COVID-19: How People Informed Themselves in the Days Following the Portuguese Declaration of the State of Emergency. Journal Media. 2020;1(1):108-121. doi:10.3390/journalmedia1010008

2. Frissen T, De Coninck D, Matthys K, D'Haenens L. Longitudinal Evidence of How Media Audiences Differ in Public Health Perceptions and Behaviors During a Global Pandemic. Front Public Heal. 2020;8. doi:10.3389/fpubh.2020.583408

3. Cloutier L, Merindol N, Pépin G, et al. Asymptomatic carriers of COVID-19 in a confined adult community population in Quebec: A cross-sectional study. Am J Infect Control. 2021;49(1):120-122. doi:10.1016/j.ajic.2020.08.015

4. Chang S, Pierson E, Koh PW, et al. Mobility network models of COVID-19 explain inequities and inform reopening. Nature. 2021;589(7840):82-87. doi:10.1038/s41586-020-2923-3

5. Azuma K, Yanagi U, Kagi N, Kim H, Ogata M, Hayashi M. Environmental factors involved in SARS-CoV-2 transmission: effect and role of indoor environmental quality in the strategy for COVID-19 infection control. Environ Health Prev Med. 2020;25(1):66. doi:10.1186/s12199020-00904-2

\section{Conflicts of interest}

The authors have declared no conflicts of interest.

\section{Acknowledgements}

To all frontline workers who are facing the COVID-19 pandemic. This study is part of the EpiSERGIPE project which is supported by grant SES/FAPESE/UFS 001/2020. The funding sources had no role in the design and conduct of the study; collection, management, analysis, and interpretation of the data; preparation, review, or approval of the manuscript; and the decision to submit the manuscript for publication. 
Table 1. Clinical characteristics and seroprevalence of SARS-CoV-2 antibodies among broadcast media workers.

\begin{tabular}{|c|c|c|c|c|}
\hline Variable & $\begin{array}{l}\text { All media workers } \\
\quad(n=113)\end{array}$ & $\begin{array}{l}\text { Production team } \\
\quad(n=62)\end{array}$ & $\begin{array}{l}\text { Reporting team } \\
(\mathrm{n}=22)\end{array}$ & $\begin{array}{l}\text { Operation team } \\
\qquad(n=29)\end{array}$ \\
\hline Age (median, IQR) & $39.0(30.0-48.0)$ & $40.0(33.3-47.0)$ & $\begin{array}{c}42.0(35.8- \\
51.8)\end{array}$ & $30.0(25.0-39.0)$ \\
\hline Sex (male) & $79(70.0 \%)$ & $40(64.5 \%)$ & $17(77.3 \%)$ & $22(75.9 \%)$ \\
\hline Comorbidities & $29(25.7 \%)$ & $19(30.7 \%)$ & $6(27.3 \%)$ & $4(13.8 \%)$ \\
\hline Close contact with someone who had COVID-19 & $42(37.2 \%)$ & $29(46.8 \%)$ & $6(27.3 \%)$ & $7(24.1 \%)$ \\
\hline Use of face mask & $110(97.3 \%)$ & $60(96.8 \%)$ & $21(95.5 \%)$ & $29(100.0 \%)$ \\
\hline \multicolumn{5}{|l|}{ Serological analysis } \\
\hline $\lg \mathrm{M}_{+}$ & $11(9.7 \%)$ & $7(11.3 \%)$ & $2(9.1 \%)$ & $2(6.9 \%)$ \\
\hline $\lg M_{+} / \lg G_{+}$ & $6(5.3 \%)$ & $4(6.5 \%)$ & 0 & $2(6.9 \%)$ \\
\hline $\lg G_{+}$ & $11(9.7 \%)$ & $5(8.1 \%)$ & $2(9.1 \%)$ & $4(13.8 \%)$ \\
\hline Seroprevalence (Cl 95\%) & $24.7(17.7-33.5)$ & $25.8(16.6-37.9)$ & $18.2(7.3-37.9)$ & $27.6(14.7-45.7)$ \\
\hline
\end{tabular}

